براورد آب مجازى و نياز آبى گياهان حاشيه بيابان با استفاده از تصاوير ماهوارهاى (مطالعه موردى: دشت ورامين)

بديعه نورى'، حميده نورى'، غلامرضا زهتابيان'، اميرهوشنغ احسانى'، حسن خسروى' و حسين آذرنيوند' (تاريخ دريافت:

جكيده

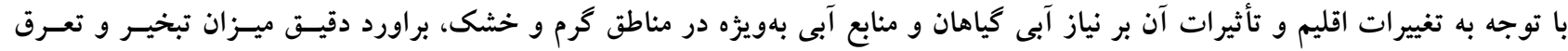

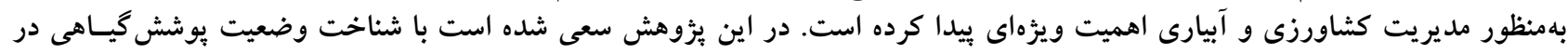

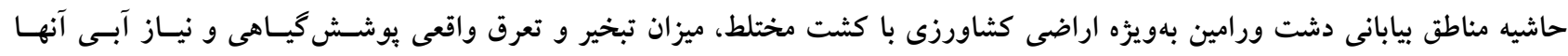

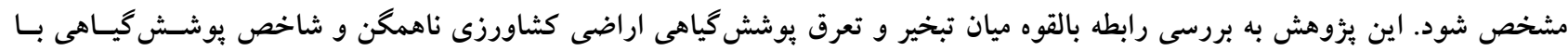

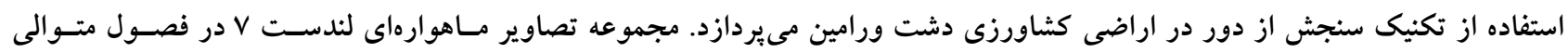

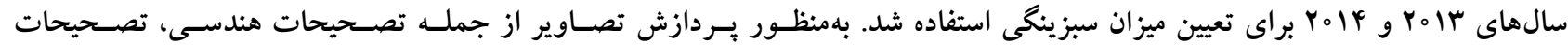

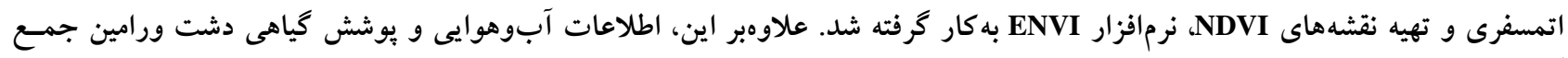

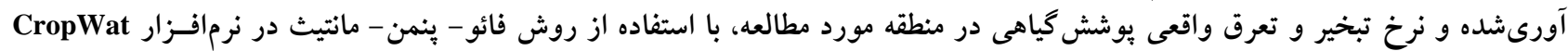

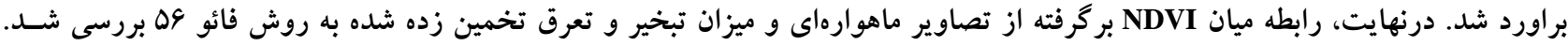

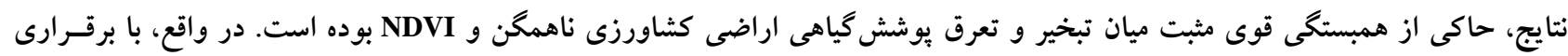

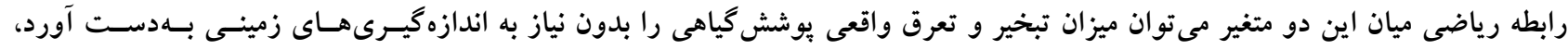

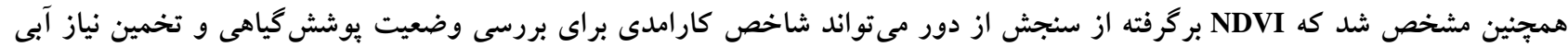
كياهان اراضى كشاورزى حاشيه بيابان باشد.

وازههاى كليدى: تبخير و تعرق، سنجش از دور، NDVI، فائو - بنمن - مانتيث، دشت ورامين

ا. گُروه احيا مناطق خشك و كوهستانى، دانشكده منابع طبيعى، دانشگاه تهران، تهران، ايران

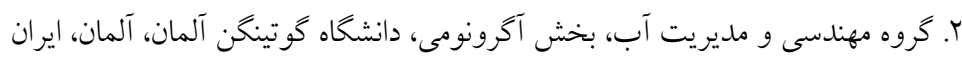

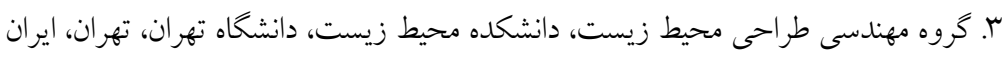

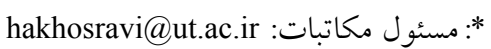


بر اكنده بيشترين بازتاب از نور مرئى و كمترين بازتـاب از نـور

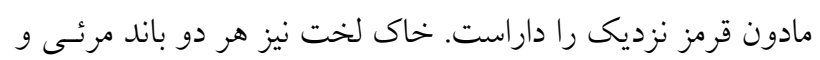
مادون قرمز نزديك را بهطور متوسط منعكس مى كند (A).

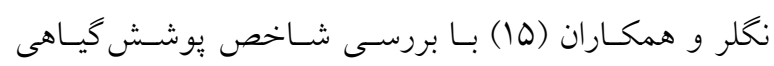

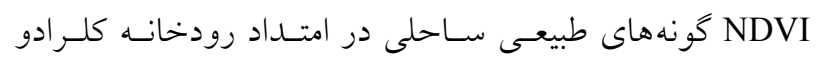
كزارش كردند كه اين شاخص اطلاعات قابل اعتمادى از فراينـدهاى فيزيولوزيكى كياهان هميجون تبخير و تعرق فراهم مى كند.

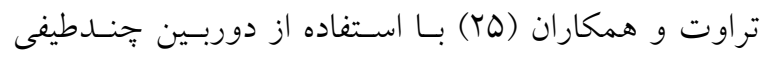

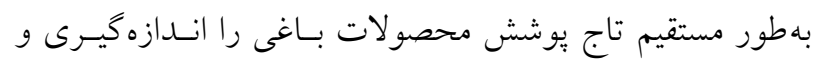
سبس تـاج يوشـش گيـاهى حاصـل از ايسن روش را بـا مقــادير

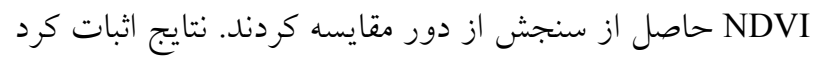

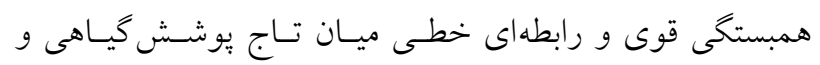

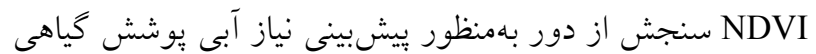
وجود دارد.

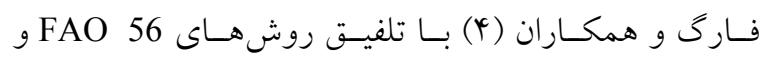
دادههاى سنجش از دور براى برنامهريزى آبيارى محصول كندم

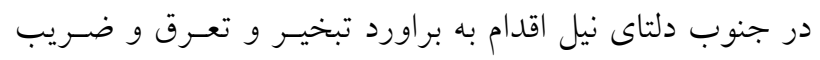

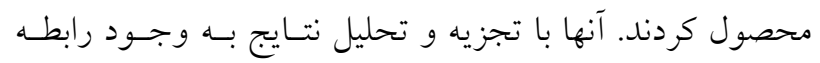

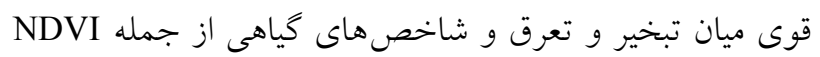
و SAVI در طول دوره رشد كياهان يى بردند. نورى و همكاران (19) براى تعيين بـراورد نيـاز آبسى كـلان

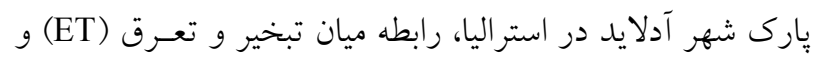

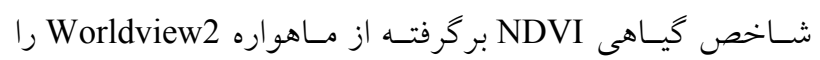
بررسى كردند. آنها به وجود همبستخى بسـيار قـوى بسين ET و NDVI

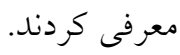

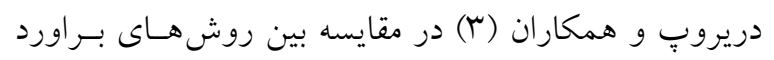

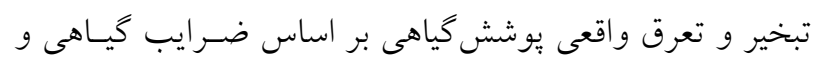

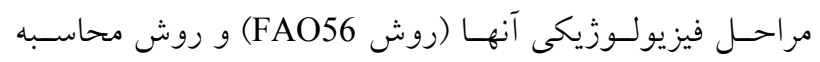
NDVI

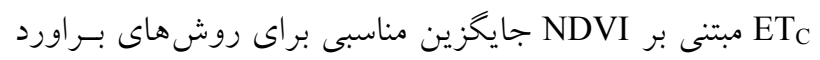
ETC

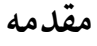

در جهان امروز، با افزايش روز افزون جمعيت و نياز بـهـ توليـــ

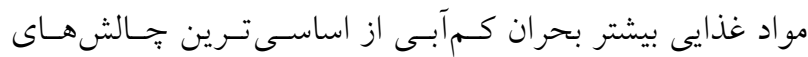

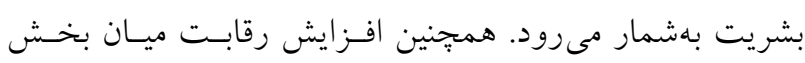

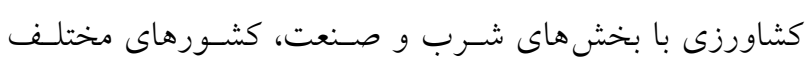

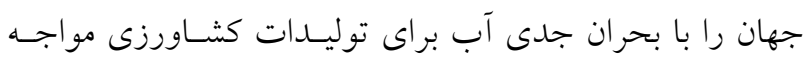
ساخته است (1) (1).

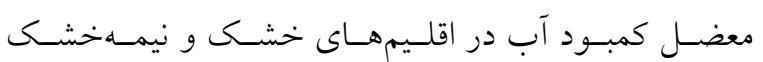

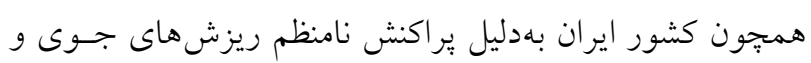

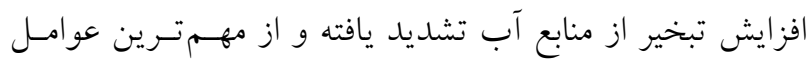
محدودكننده توسعه اجتماعى و اقتصادى است. در ايـن منـاطق، بهمنظور دستيابى به توليد و بهروورى بيشتر محصولات، اقدام به ونه

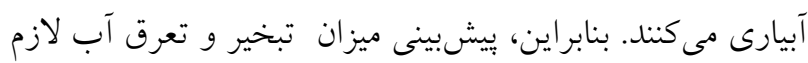

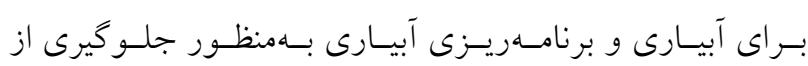

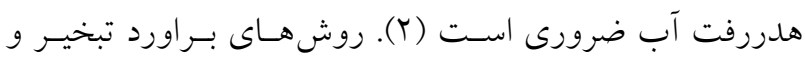

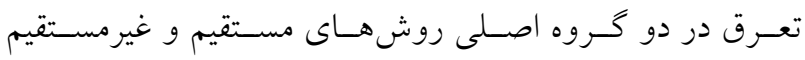

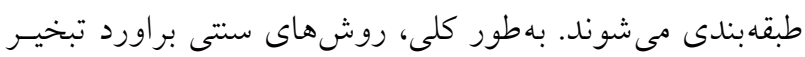

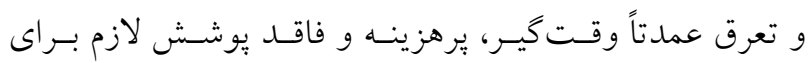

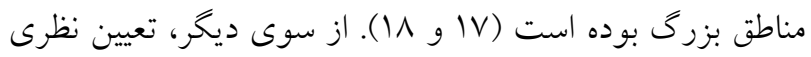

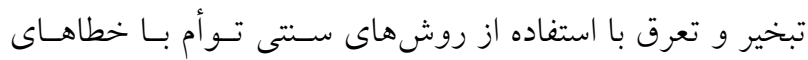

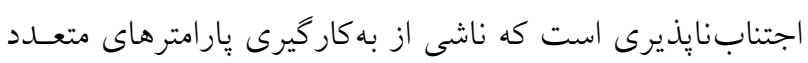

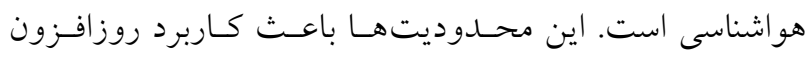

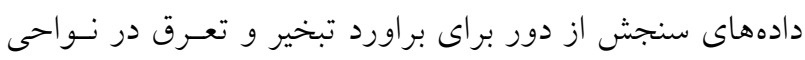

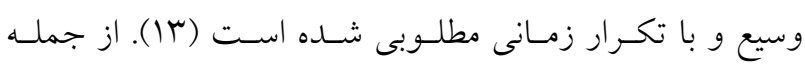

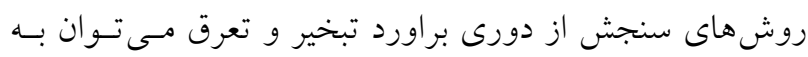

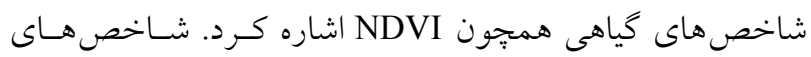

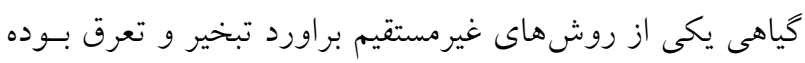

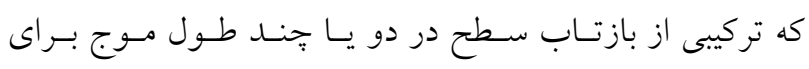

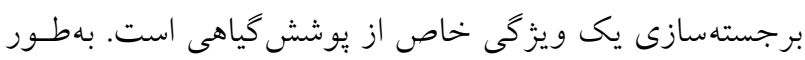

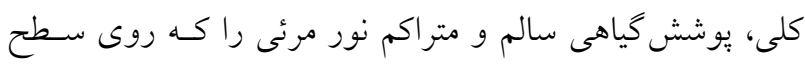

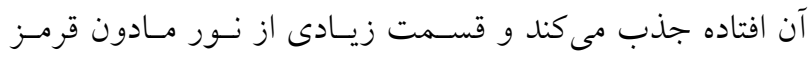

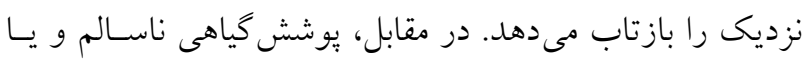




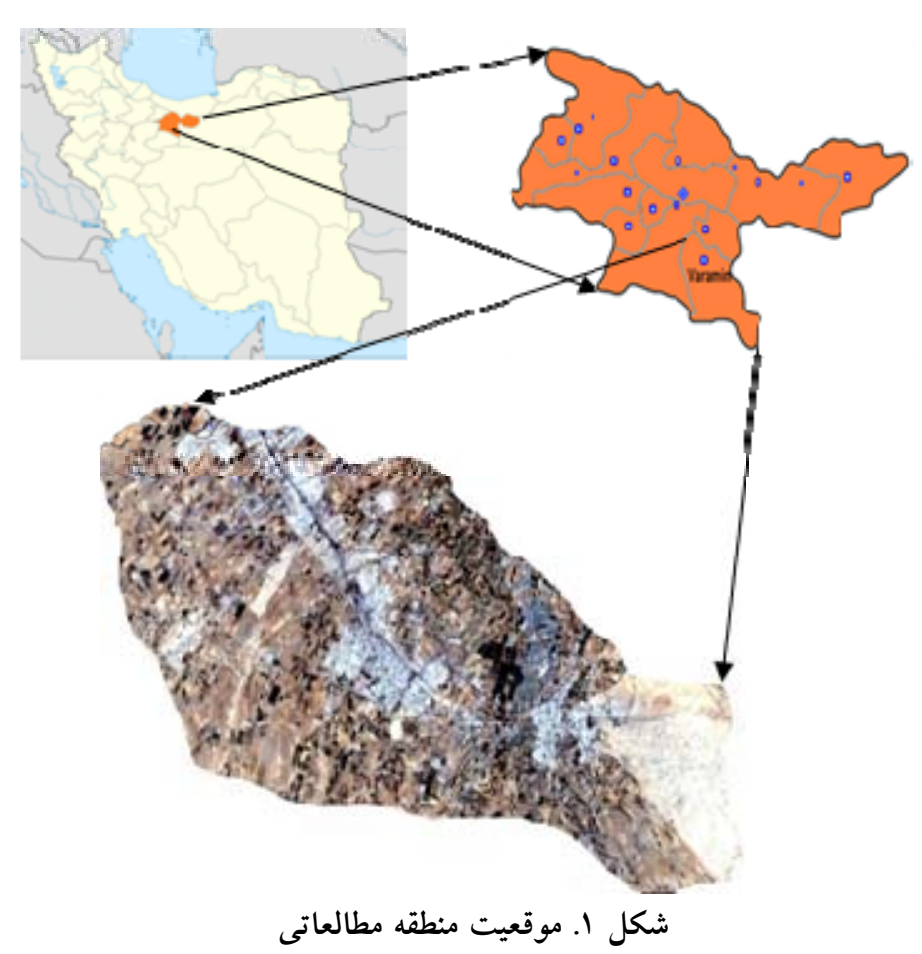

متوسط بارندگى ورامين بر اساس آمار وبس سـاله تبخيرسـنج مؤسسه اصلاح بذر ورامين 191/0V ميلسىمتـر در سـال استـ.

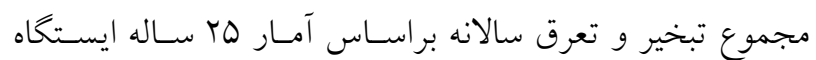

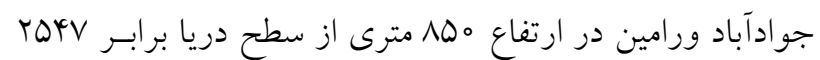
ميلى متر است (V و Y Y Y). دشت ورامين داراى قدمت كشـاورزى بوده كه بهعلت نزديكى به تهران مسى تـوان كفـت يـك بـازوى

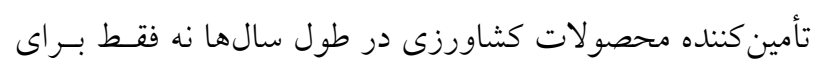
تهران بلكه ساير نقاط كشور نيز بـوده اسـت. مسـاحت اراضسى قابل كشت و سطح زير كشت خالص دشت ورامسين بـهترتيـب

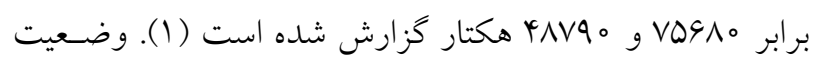
موجود الكوى كشت (سطح زير كشت انواع محصولات زراعى آبى و باغى آبى) و تركيب كشت (درصد محصولات زراعى آبى و باغى آبى) در جدول (1) آورده شده است (آبى (ب).

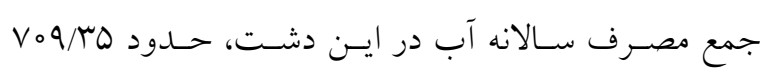
ميليون مترمكعب بوده است كه NV/T درصــ از آن بـه مصسرف كشاورزى منطقه مىرسد ( (1). از مهم تـرين شـبكههــاى آبيـارى

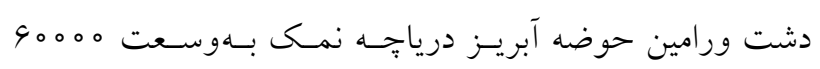
هكتار است كه بخش غالب اراضى دشـت را تحست أتـأثير قـرار

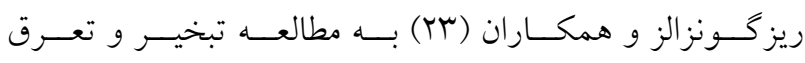

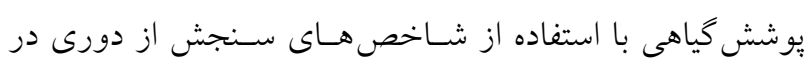

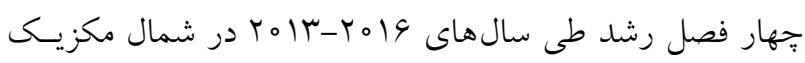

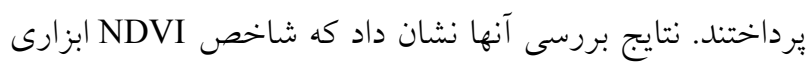
مفيد براى انــازهذيـرى ميـزان تبخيـر و تعـرق و مصـرف آب لبر كشاورزى است. در كشور بهويزه در مناطق خشك و بيابانى، تا كنون كمتر به مطالعات سنجش از دورى با اسـتفاده از شـاخصهـاى گيـاهى براى براورد تبخير و تعرق واقعى بوشش گيـاهى برداختـه شــه

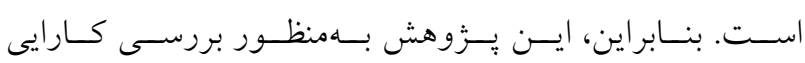

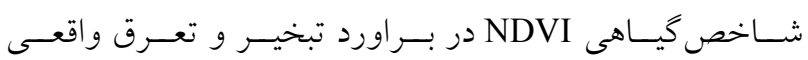
يوشش گياهى در اراضى كشاورزى انجام شده است.

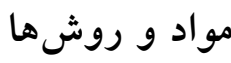 منطقه مورد مطالعه}

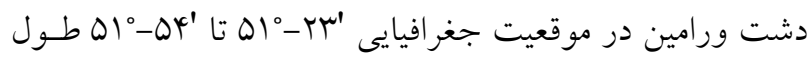

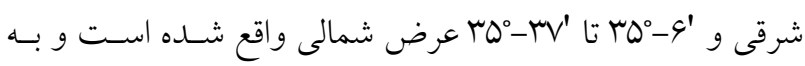
فاصله هY كيلومترى جنوب شرقى تهران قرار دارد (شكل (1). 
جدول ا. وضعيت كثاورزى دشت ورامين

\begin{tabular}{|c|c|c|c|c|c|c|c|c|c|c|c|c|c|c|c|}
\hline 客. & 3" & $\frac{v}{2}$ & $\begin{array}{c}13 \\
1 \\
3 \\
13 \\
13\end{array}$ & $\frac{9}{\frac{3}{3}}$ & $\begin{array}{l}1 \\
3 \\
0 \\
0\end{array}$ & 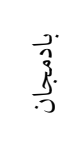 & $\hat{y}_{j}$ & $\begin{array}{l}3 \\
3 ? \\
?\end{array}$ & $\frac{3}{3}$ & . & $\hat{3}$ & 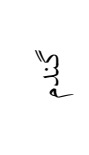 & ji & $\overrightarrow{1}$ & \\
\hline rolor & rQ。 & $r^{\prime} 0_{0}$ & yoo & 0.9 & $10 \mathrm{~V}$ & 900 & 919 & "r人。 & INT。 & rqur & $\Delta V \Delta_{0}$ & 9100 & 1.400 & ha & مساحت \\
\hline 100 & $0 / 99$ & $0 / N V$ & $1 / 11$ & $1 / 1$ & $1 / 1$ & $1 / 99$ & $r / 99$ & $r / \Lambda 1$ & $0 / 09$ & $10 / N F$ & $10 / \wedge 9$ & $r D / /{ }^{c}$ & TN/FG & ha & درصد \\
\hline
\end{tabular}

نوارشـــى، تصـحيحات هندسى و تصـحيحات اتمسـفرى بـا

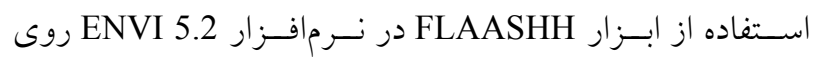

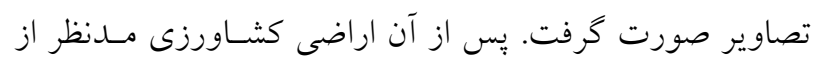

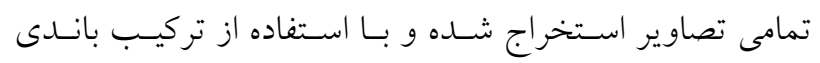

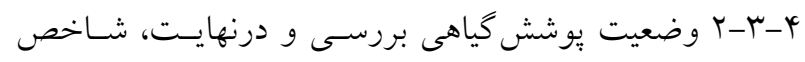

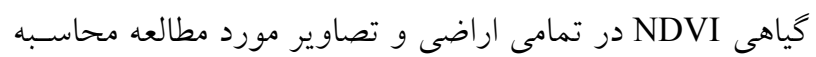

لازم بهذكر اسـت كـه در بسـيارى از مـاهوارههـا، شـاخص

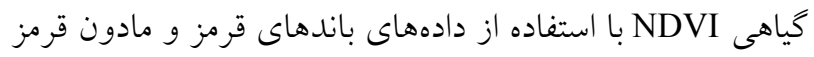
نزديك محاسبه مىشود: $\mathrm{NDVI}=\frac{\rho_{\mathrm{NIR}}-\rho_{\text {red }}}{\rho_{\mathrm{NIR}}+\rho_{\text {red }}}$

كه م تشعشع ثبتشده در باند طول موج مادون قرمز نزديك و و تشعشع ثبت شده در باند طول موج مادون قرمز ماهواره

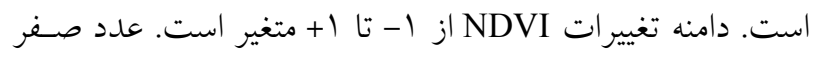

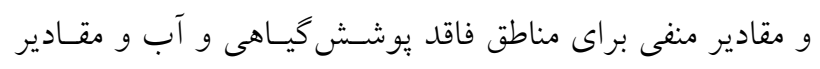

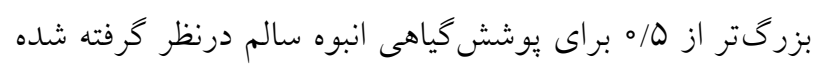

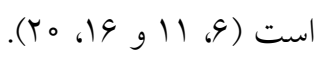

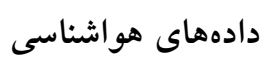

بهمنظور براورد ميـزان تبخيــر و تعـرق كيـاه مرجـع، اطلاعــات

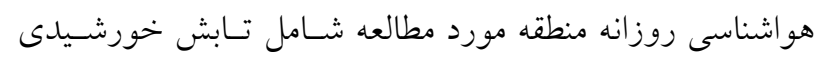
(ساعات آفتابى)، بيشينه و كمينه دماى هوا، رطوبت نسبى هوا و و موردئ

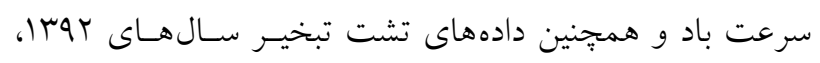

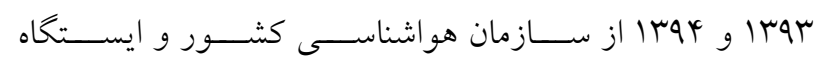
هواشناسى شهرستان ورامين دريافت شد.
مى دهد. به لحاظ كمبود منابع آب سطحى و نايايدارى آن بـراى

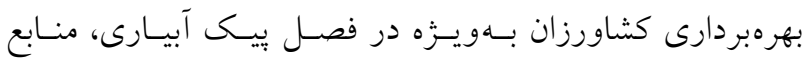

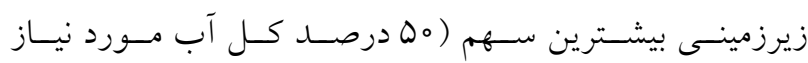
كشاورزان) را در تأمين آب محصولات كشـاورزى دارا هستيتند.

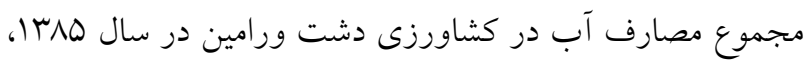

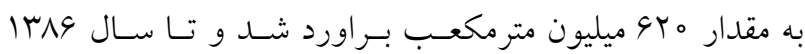

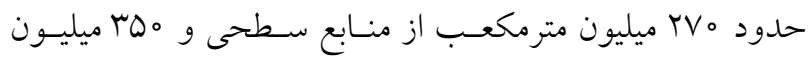

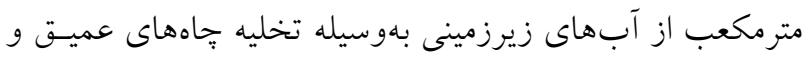
نيمهعميق تأمين مىشد (9).

\section{دادههاى ماهوارهاى و بردازش تصاوير}

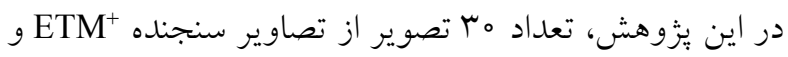

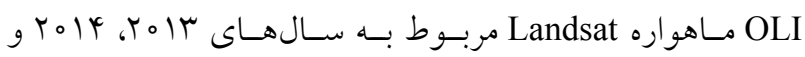

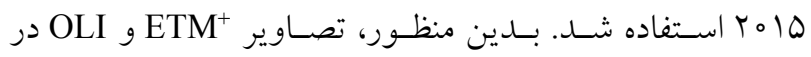

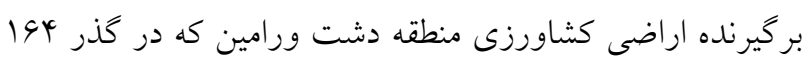
و رديف كب ماهواره لندست V Vقـرار داشـته از سـايت سـازمان

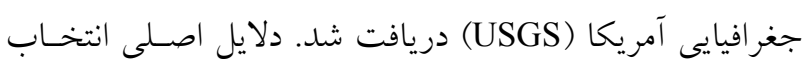

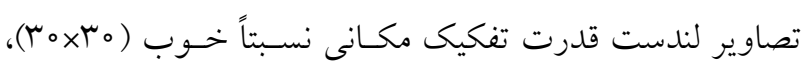

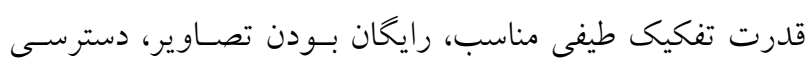

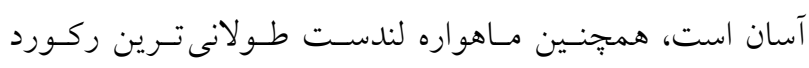

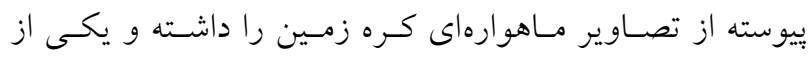

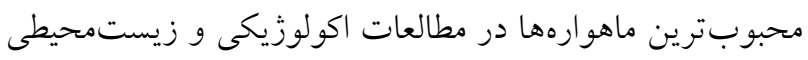
بيش از هر كونه تجزيسه و تحليـل روى تصـاوير، دادهــاى

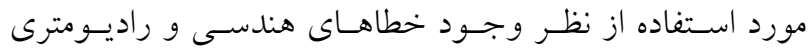

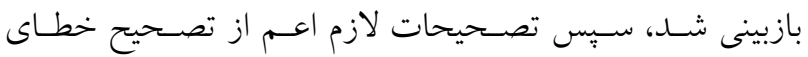




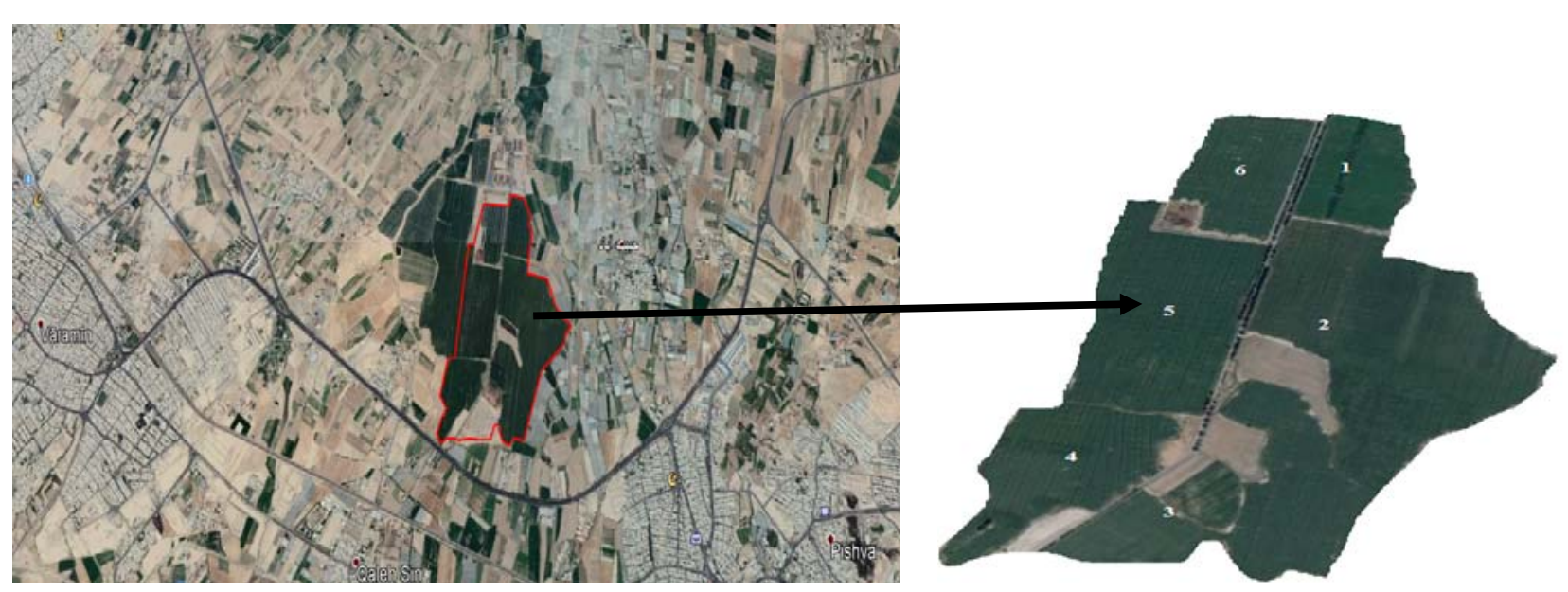

شكل r. اراضى كشاورزى مورد مطالعه در كشت و صنعت جارتاسيان

بر اساس نظر كارشناسان و يا آزمـايش در يـك منطقـه آبيـارى تنظيم مى شود.

دادههاى يوشش گياهى به منظور تعيين ضرايب گياهى و براورد تبخير و تعرق واقعى توسى يوشش كياهى، مطالعات ميدانى در سـطح اراضسى كشـاورزى دشت ورامين صورت بذيرفت. يس از بررسى اراضى منطقـه

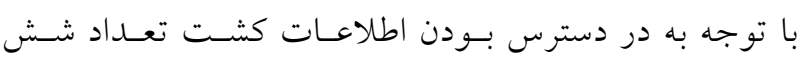

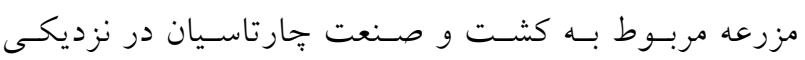

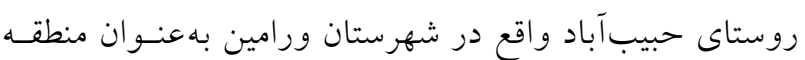

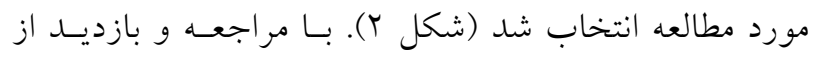
اين مزارع اطلاعات مربوط به اراضى كشـاورزى شـامل نـوع محصولات، زمان كاشـت و برداشـت محصـولات، مسـاحت اراضى و غيره جمع آورى شد. بر اسـاس ايسن اطلاعـات، دو كشت عمده اراضى كشـاورزى مـــكور، محصـولات زراعسى

$$
\text { شامل ذرت علوفهاى و يونجه هستند. }
$$

مشخصـات هـر يـك از اراضـى كشــاورزى مــورد مطالعـهـ

همجِون نـوع محصـول، مسـاحت و دوره كشـت محصـول در جدول (Y) نشـان داده شــده اسـت. بـس از تعيسين مشخصـات يوشش گياهى، مقــادير ضــايب گيـاهى مـورد نيـاز از ضـرايب بهدست آملده توسط فرشى (ه) در كتابى با عنوان "آب مورد نياز

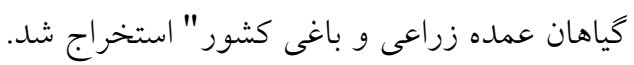

دادهاى تبخير و تعرق واقعى

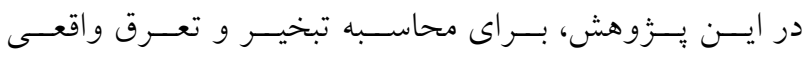
يوشش گياهى، روش FAO-56 استفاده شد. اساس اين روش دو مرحلهاى بدين صورت است كه ابتدا ميـزان تبخيـر و تعـرق گيـاه مرجع (ET0) با استفاده از روش فائو - بنمن - مانتيث تخمسين زده

مى شود (رابطه r).

$$
\mathrm{ET}_{\circ}=\frac{0, \kappa_{\circ} \wedge^{\circ} \Delta\left(\mathrm{R}_{\mathrm{n}}-\mathrm{G}\right)+{ }^{\circ} \gamma^{\circ} \frac{{ }^{900}}{\mathrm{~T}+\mathrm{r}{ }^{\mu}}{ }^{\circ} \mathrm{U}_{\mathrm{r}}\left(\mathrm{e}_{\mathrm{S}}-\mathrm{e}_{\mathrm{a}}\right)}{\Delta+{ }^{\circ} \gamma^{\circ}\left(1+0, \mu^{\circ}{ }^{\circ} \mathrm{U}_{\mathrm{r}}\right)}
$$

كه در آن ET

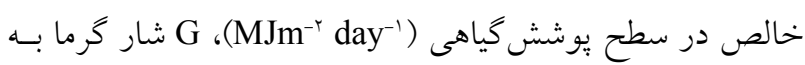
داخل خاى (

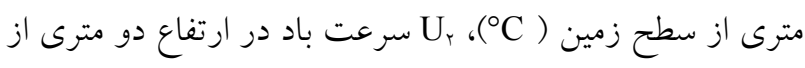

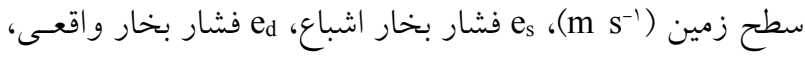
ه شيب منحنى فشـار بخــار ( است. $\left(\mathrm{KPa}^{\circ} \mathrm{C}^{-1}\right)$ در مرحله بعدى، تبخير و تعرق واقعى گياه مورد نظر از حاصل

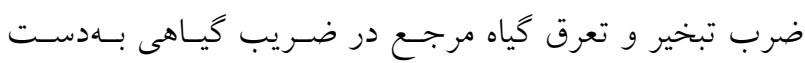
مى آيد: $\mathrm{ETc}=\mathrm{Kc} . \mathrm{ET}$ 。

ضرايب گياهى در طول جرخه رشد محصـول بـر طبـق مرحلـه رشد كياه تغيير مىيابند. اين ضرايب اغلب براى شـرايط محلى صرى 
جدول r. مشخصات اراضى كشاورزى كشت و صنعت جارتاسيان

\begin{tabular}{|c|c|c|c|c|c|c|}
\hline شش & ينج & جهار & سه & دو & يكى & شماره زمين \\
\hline ذرت علوفهاى & ذرت علوفهاى & ذرت علوفهاى & ذرت علوفهاى & ذرت علوفهاى & يونجه & محصول \\
\hline \multirow[t]{2}{*}{$1 \wedge$} & ro & 10 & 10 & هr & 11 & مساحت (هكتار) \\
\hline & \multicolumn{3}{|c|}{ كشت اول: دهه اول فروردين الى دهه اول تير ماه } & & دهه اول مهر الى ارديبهشت & دوره كشت \\
\hline
\end{tabular}

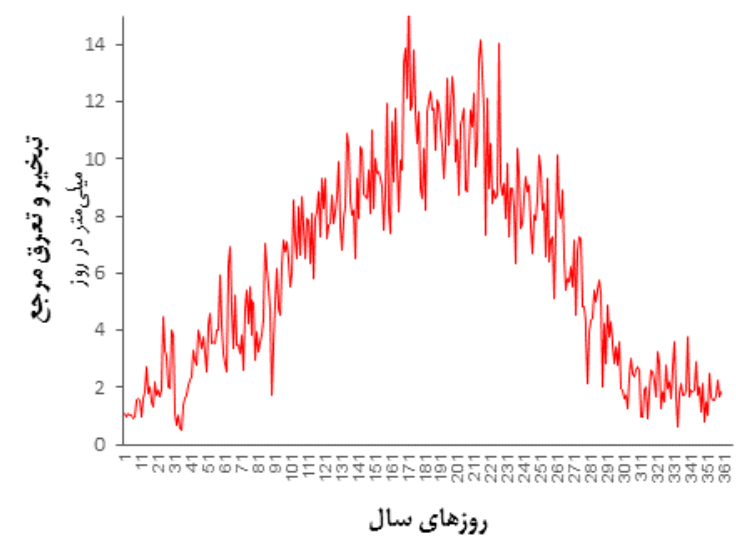

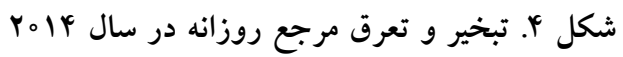

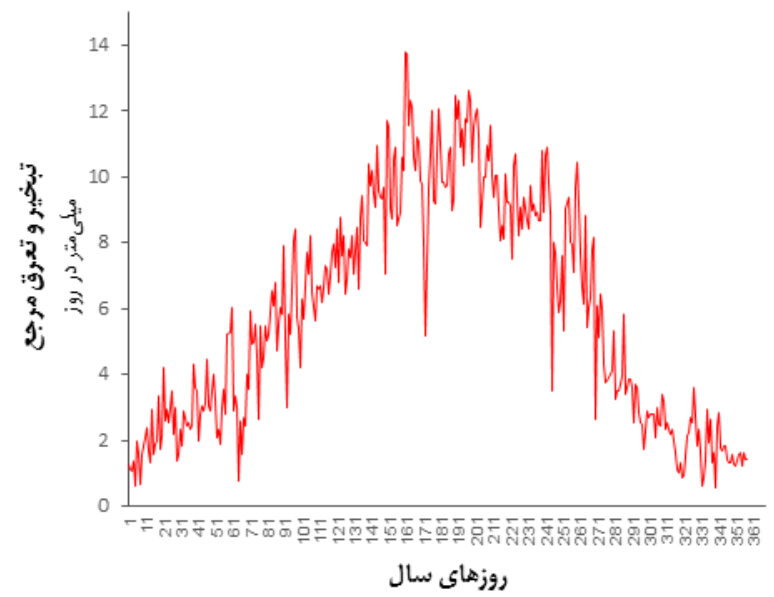

شكل r. تبخير و تعرق مرجع روزانه در سال ساه r

مربوط به يونجه و ذرت علوفهاى بهصورت ه ا روزه مشـخص شد. با توجه به شكل هاى ه و و، ميزان تبخيـر و تعـرق واقعى ئر ذرت علوفهاى در هر دو دوره كشت (فروردين تا تير و تيـر تـا

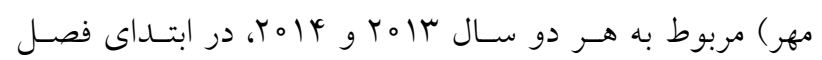

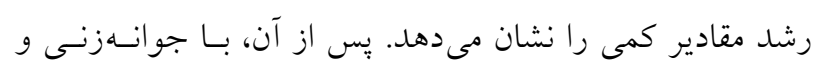
وارد شدن كياه به مرحله رويشى، بخشى از آب مصسرفى گيـاه صرف تعرق مىشود. با رشد برگها و افزايش نمايه سطح برگ، نياز آبى كياه افزايش يافته و سهم تعرق در تلفات آب بر تبخيـر از سطح خاك يِشى مى گيرد. در مراحل يايانى رشد، ميزان تبخيـر

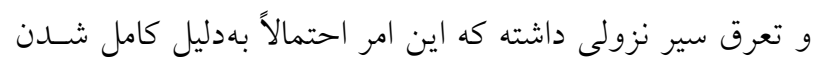
دوره رشد كياه است. با توجه به نتايج حاصل از براورد تبخير و تعرق واقعى يونجسه در هر دو سال مورد مطالعه، با كذشت زمان و وارد شـدن گيـاه از مرحله رشد اوليه به مراحل بعدى و افـزايش رشـــ بـرگهــا، ميزان تعـرق از بوشـش گيـاهى يونجــه افـزايش مسىيابـد. ايسن

نتايج و بحث تبخير و تعرق گياه مرجع بر اساس نتايج بهدست آمــده از بــراورد ميـزان تبخيـر و تعـرق

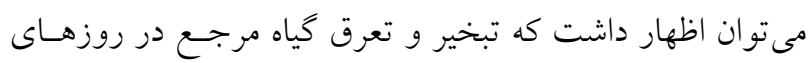
ابتدايى و انتهايى سال كه يارامترهاى هواشناسى داراى مقادير و

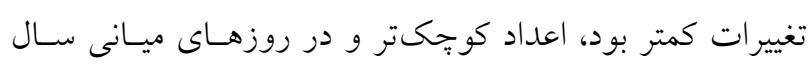

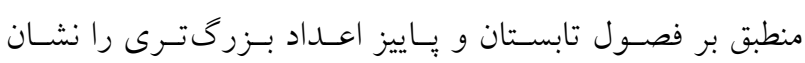

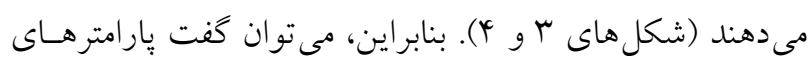
هواشناسى از جمله ساعات آفتابى، دمـاى هـو ا، سـرعت بـاد و غيره تنها عو امل مؤثر بر ميزان تبخير و تعرق گياه مرجع هستند.

تبخير و تعرق واقعى هِ از محاسبه تبخير و تعرق مرجع و اعمال ضرايب گياهى در روش فائو وه، ميـزان تبخيـر و تعـرق واقعى يوشـش گيـاهى 


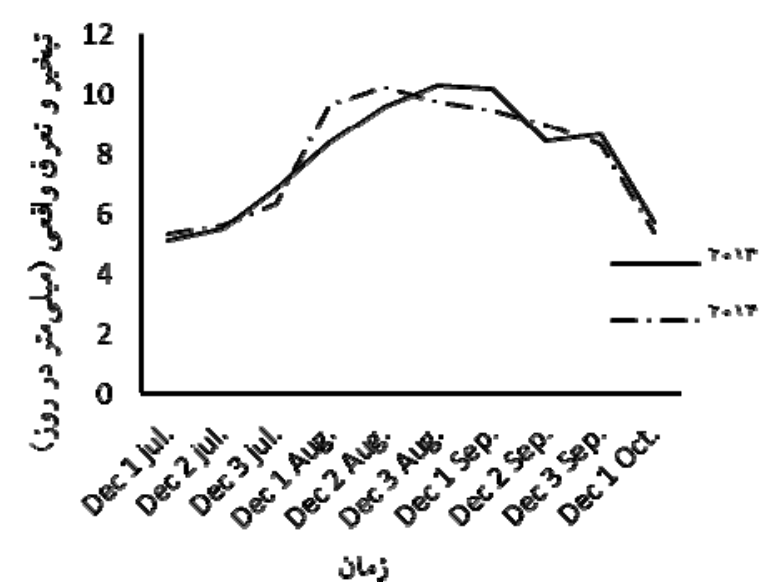

شكل و. ميزان تبخير و تعرق واقعى كشت دوم ذرت

علوفهاى در سالهاى زراعى r.|r-Yo|r

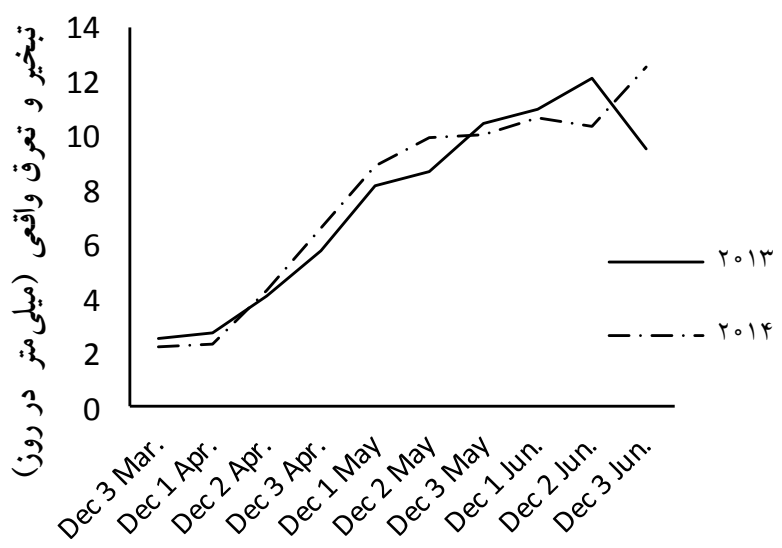

زمان

شكل ه. ميزان تبخير و تعرق واقعى كشت اول ذرت

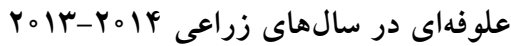

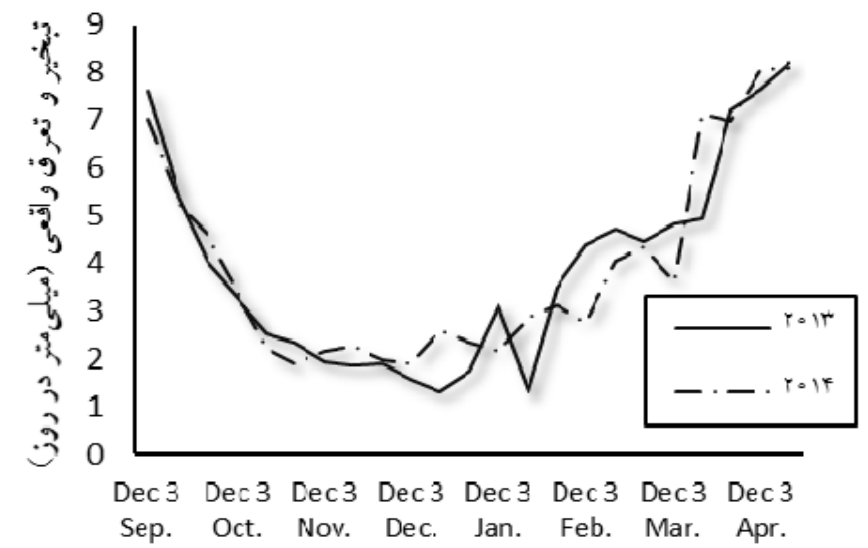

زمان

شكل V. ميزان تبخير و تعرق واقعى يونجه در سالهاى زراعى Yo|r-Y0|Y

كشت، مقدار شاخص NDVI افزايش يافتـه اسـت. ايـن تغييـر، نشاندهنده افزايش تراكم و همخنتر و يكدست شدن يوشـش زمين است. بهطورى كه در انتهاى مراحل رشـــ و در مـاههـاى نزديك به عمليات برداشت كه يوشش زمين بيشـترين تـراكم را دارد، NDVI داراى بيشترين مقادير است.

ارتباط تبخير و تعرق واقعى و شاخص NDVI بهمنظور بررسى رابطه ميان تبخير و تعرق واقعى ذرت علوفهاى و يونجسه و شـاخص NDVI در اراضسى كشـاورزى كشـت و
درحالى است كه بـا نزديـك شــن بـهـ فصـل سـرما و كـاهش فعاليتهاى فيزيولوزيكى گياه و كاهش رسانايى روزنهاى، ميزان تعرق از يوشش گياهى كاهش يافت و تغييرات كمترى را نشـان مىدهد. يس از آن، همراه با افزايش دماى هوا به بالاتر از دمـاى يايه فيزيولوزيكمى كياه، فعاليت كيـاه نيـز افـزايش يافـت و ايسن موجب افزايش تعرق از بوشش گياهى مىشود (شكل V). شاخص يوشش گياهى با استفاده از دادههاى ماهواره لندست بر اساس نتايج حاصل از محاسبه مقادير شاخص گياهى NDVI مىتوان كفت كه با كاشت گياه و سبز شـدن آن در طـول زمـان 


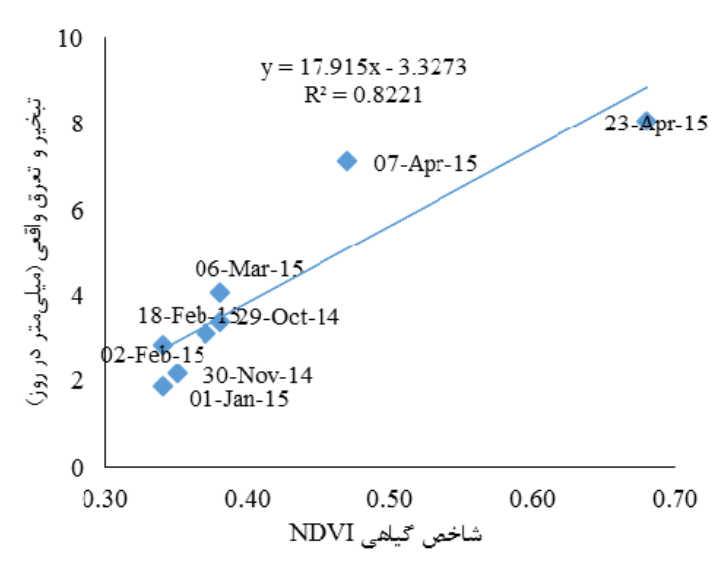

شكل 9.

در سال rolf

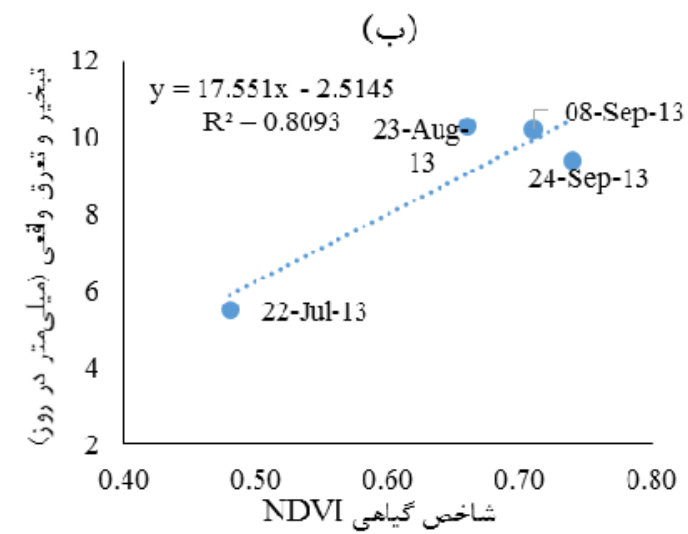

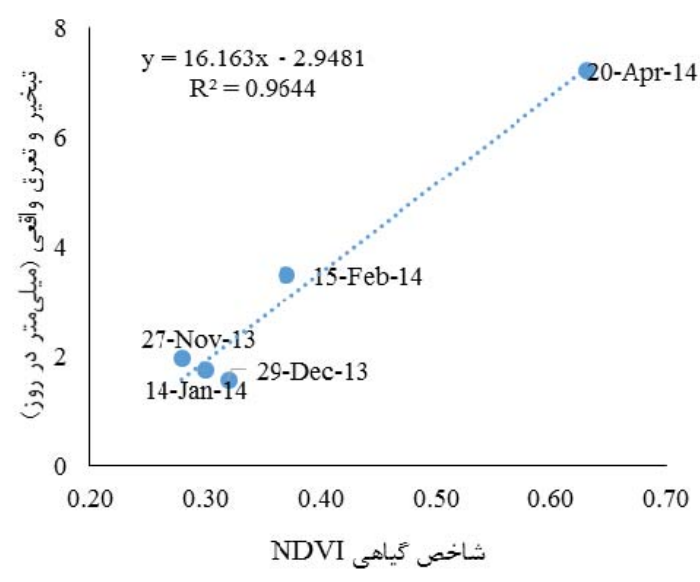

شكل ^م ارتباط مقادير NDVI-ETC در زمين شماره يك (يونجه) در سال rolron

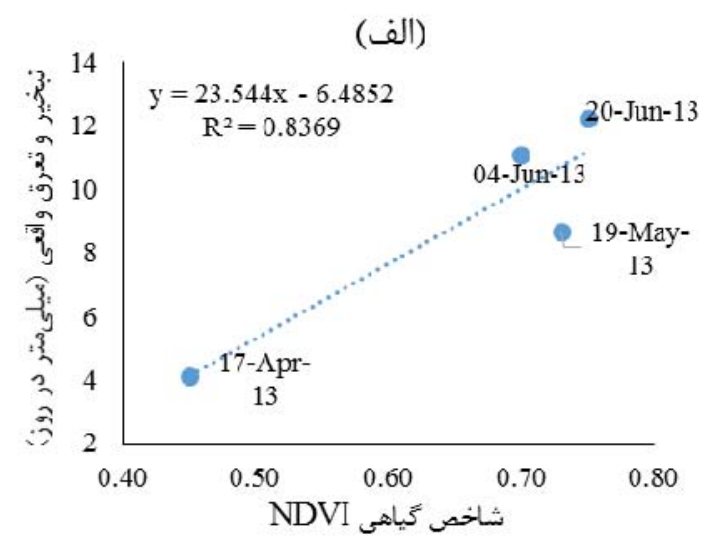
شكل ه ا. ارتباط مقادير NDVI-ETC در زمين شماره دو در سال باهY: الف) كشت اول و ب) كشت دوم

نتايج حاصل از زمينهاى شماره دو الـى شـش زيسر كشـت

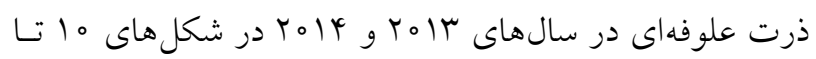

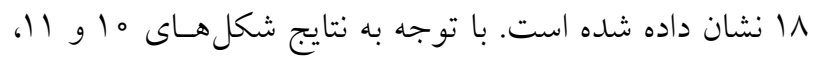
ميان شاخص NDVI و تبخير و تعرق واقعى ذرت علوفـهاى در زمين شماره دو طى دو سال مطالعه و در طـول دو دوره كشـت همبستخى قوى و مثبتى وجود دارد. نتايج حاصل از زمين شماره سه (شكل هاى باى و م||) نشان مىدهد كه روند ثابتى ميان تغييـرات NDVI و ETC

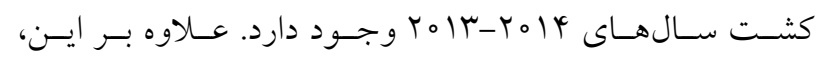
همبستكى خوبى ميان اين دو متغير بـهـــز در دوره اول كشـت

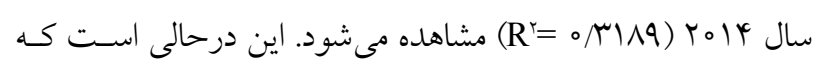

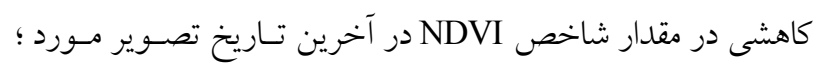

صنعت جارتاسيان، ضريب همبستخى و معادله ركرسيونى ميـان دو متغير ETC و NDVI در هر يكى از زمينهاى مـورد مطالعـه طى دو سال Y |Y

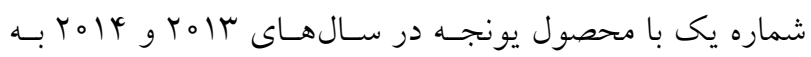
ترتيب در شكل (N) و (9) ارائه شده است.

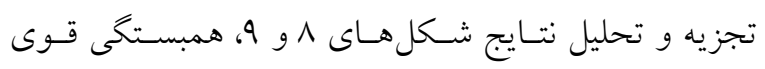

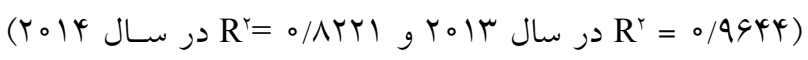
را ميان شاخص NDVI بهدست آمده از تصاوير ماهواره لندست و تبخير و تعرق محاسبه شـده از روش فـائو وهل در زمـين زيـر كشت يونجه در دو سال مطالعه نشان مىدهد. اين ارتباط قـوى حاكى از اين است كه با رشد بوشش گياهى و افزايش تراكم آن، ميزان تبخير و تعرق افزايش بيدا مى كند. 

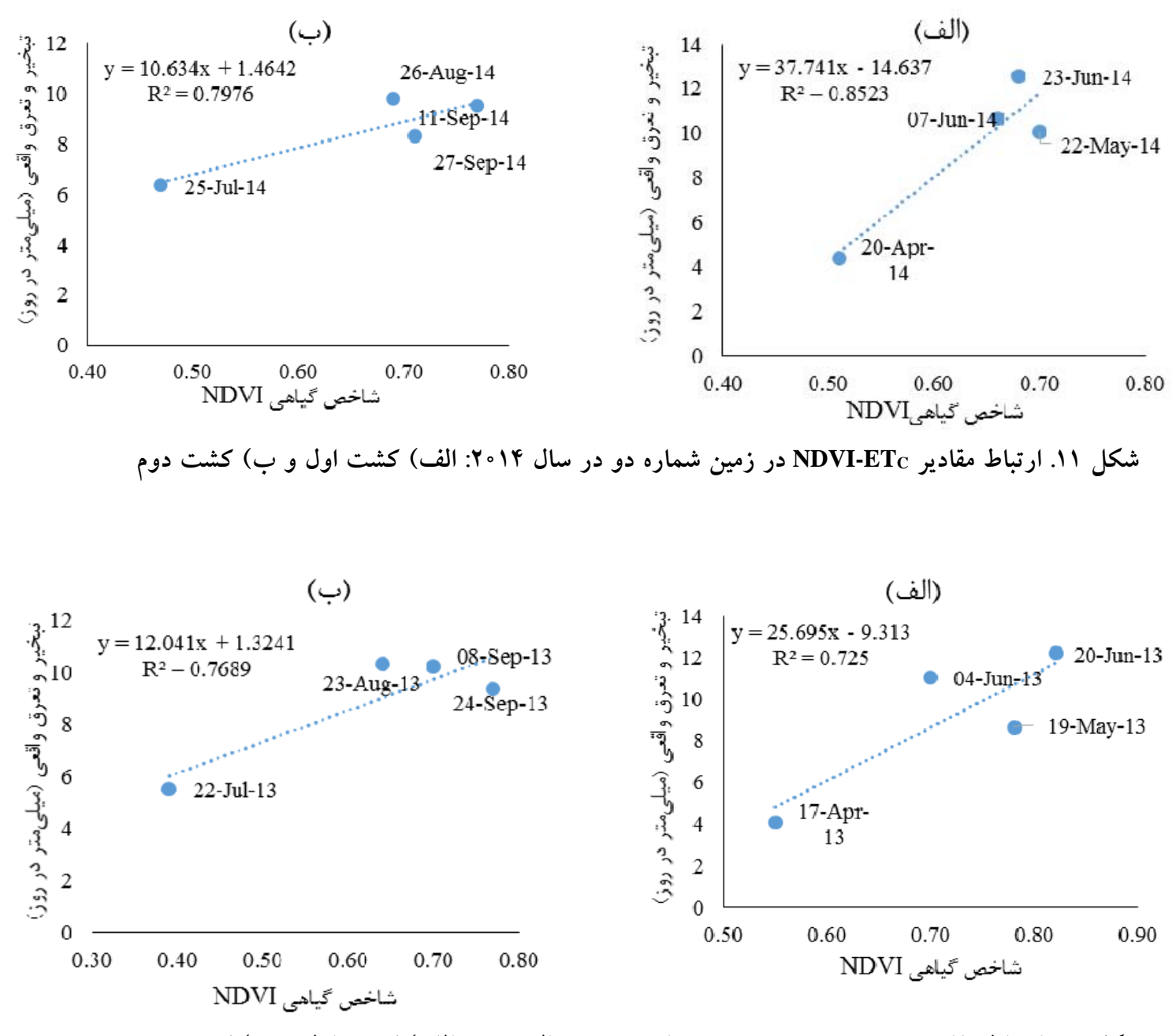

شكل rا. ارتباط مقادير NDVI-ETC در زمين شماره سه در سال ساهץ: الف) كشت اول و ب) كشت دوم
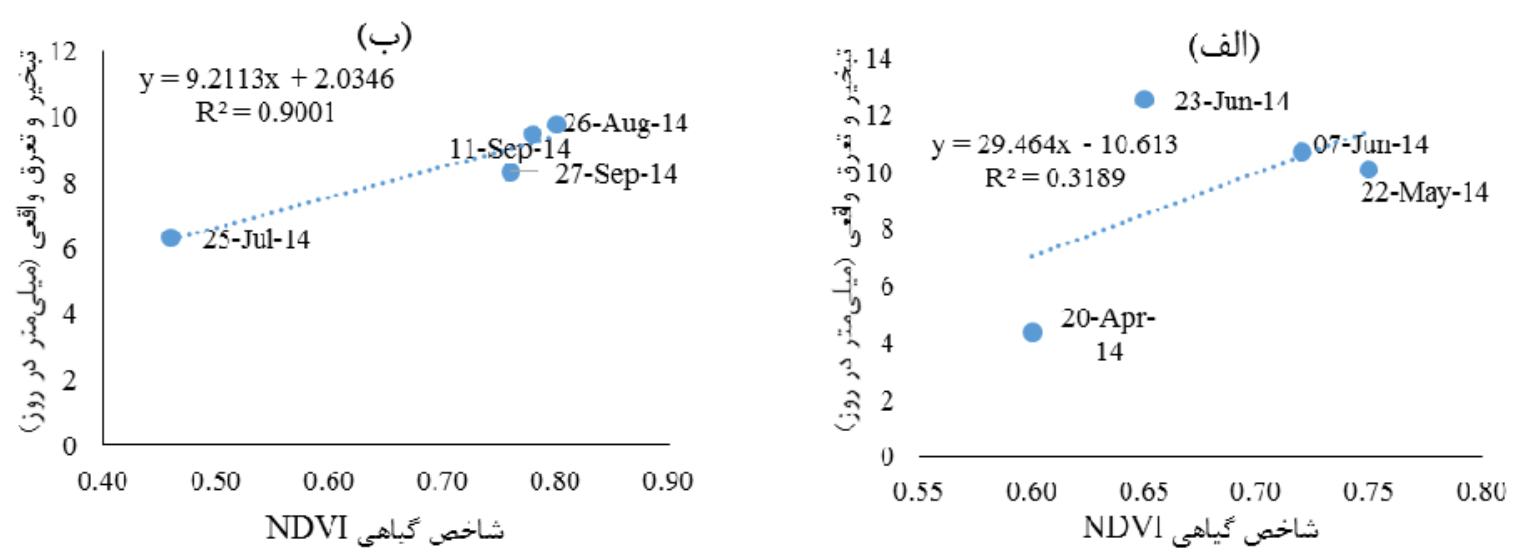

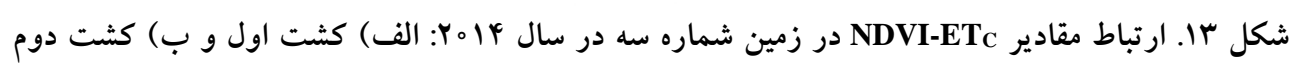

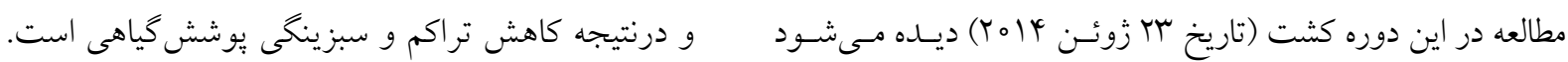
دليل اين امر نيز برداشت بخشى از محصولات در اوايل تير مـاه تجزيه و تحليل نتايج شكلهاى أ| و ها نشان مىدهد كه 

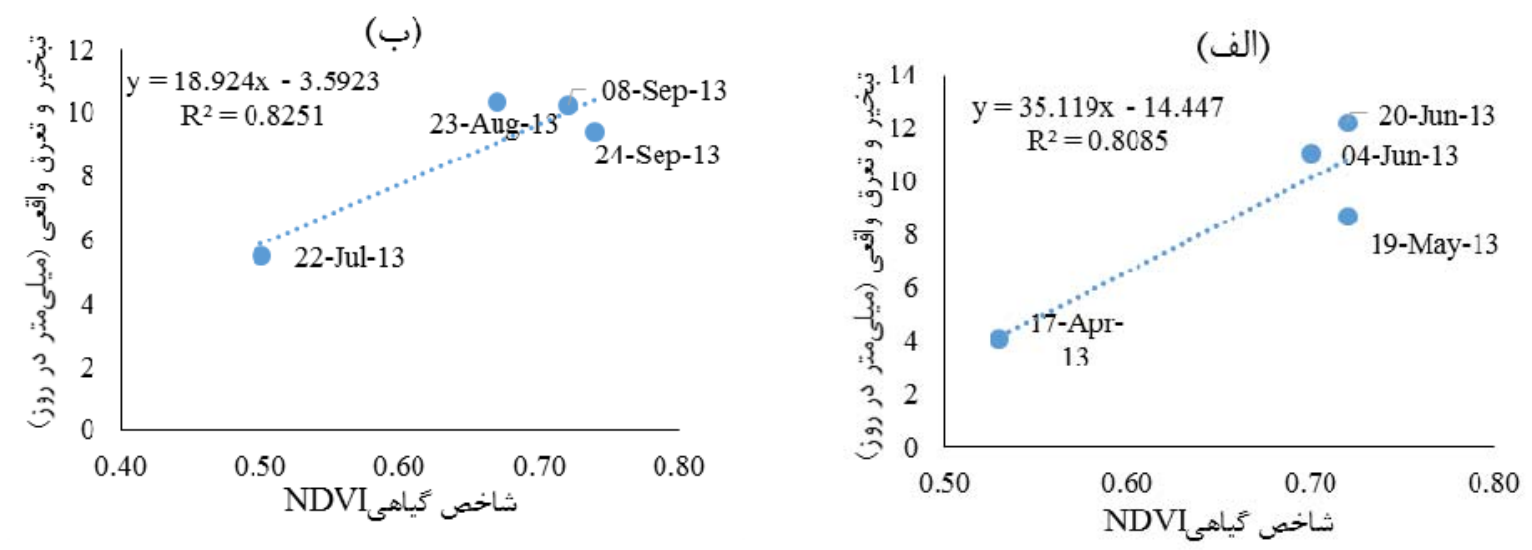

شكل If دDVI-ETC در زمين شماره جهار در سال rاهب: الف) كشت اول و ب) كشت دوم
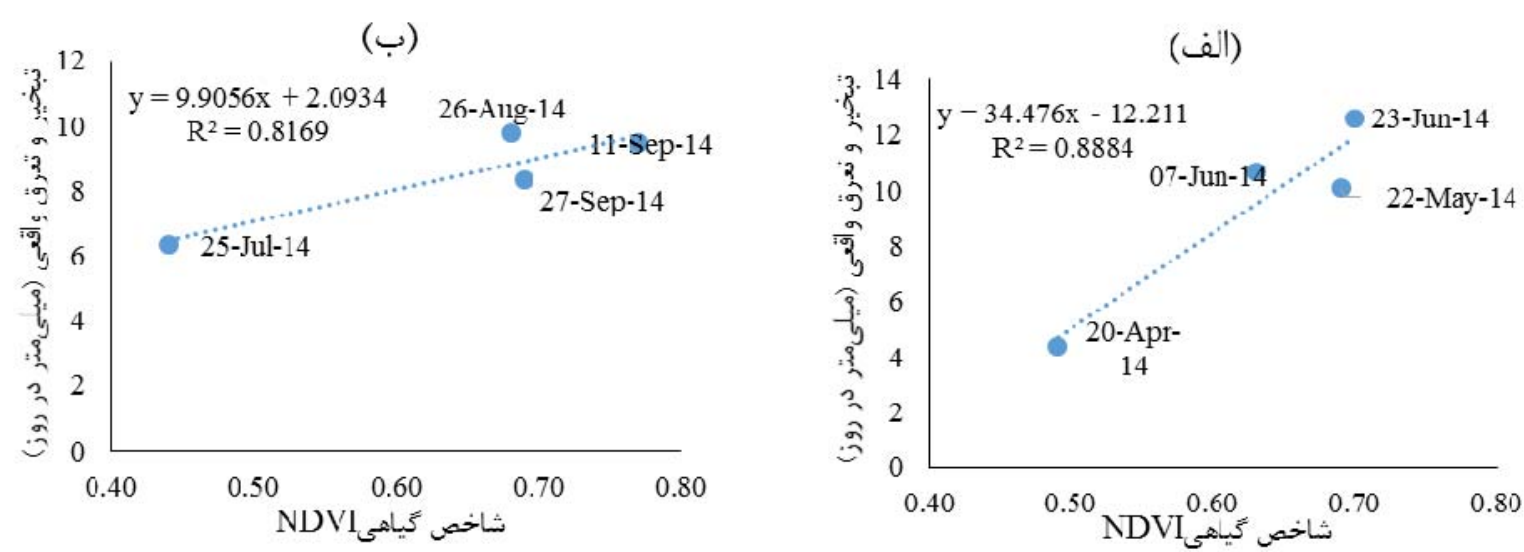

شكل 10. ارتباط مقادير NDVI-ETC در زمين شماره جهار در سال \& اهب: الف) كشت اول و ب) كثت دوم
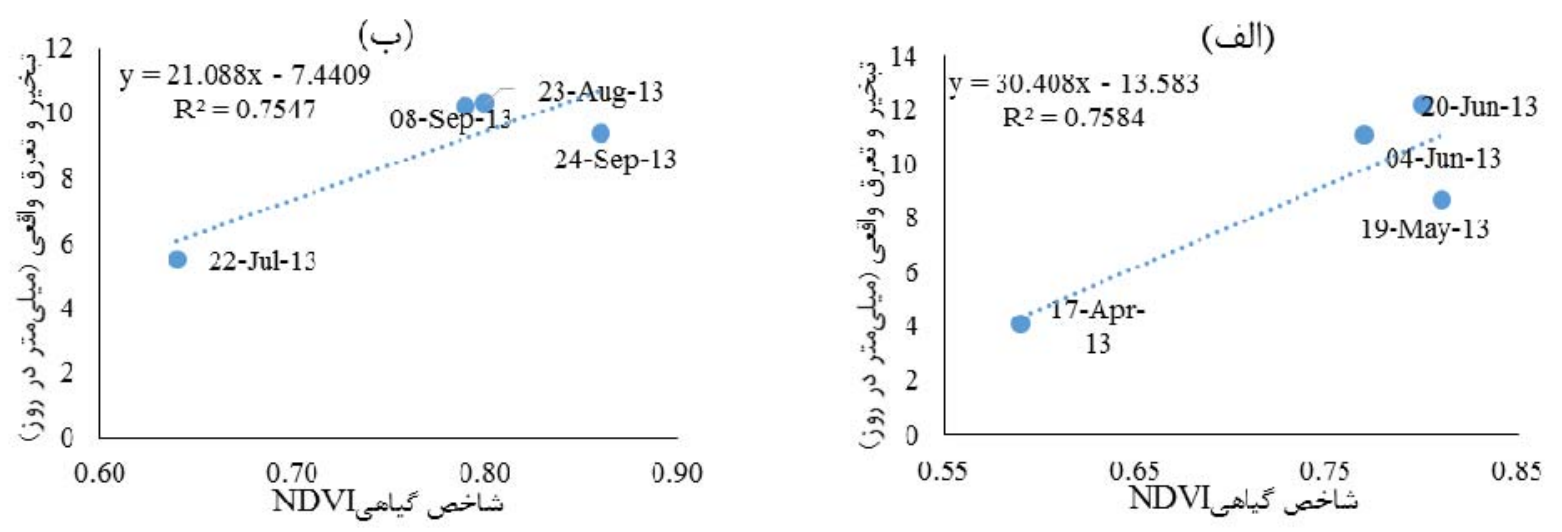

شكل 19. ارتباط مقادير NDVI-ETC در زمين شماره بنج در سال rاهץ: الف) كثت اول و ب) كشت دوم

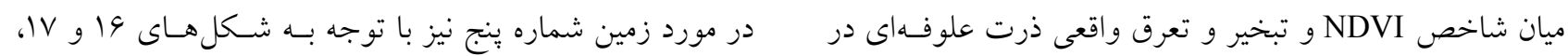

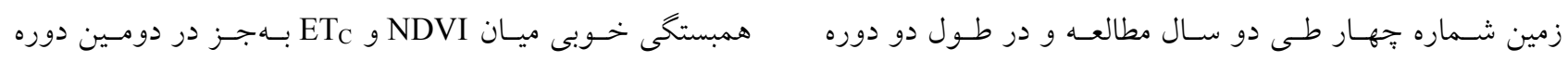

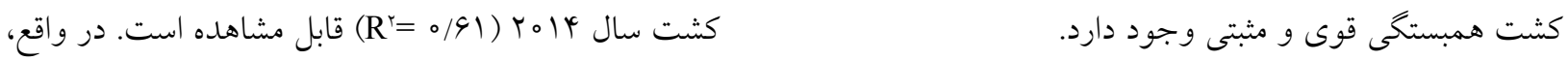




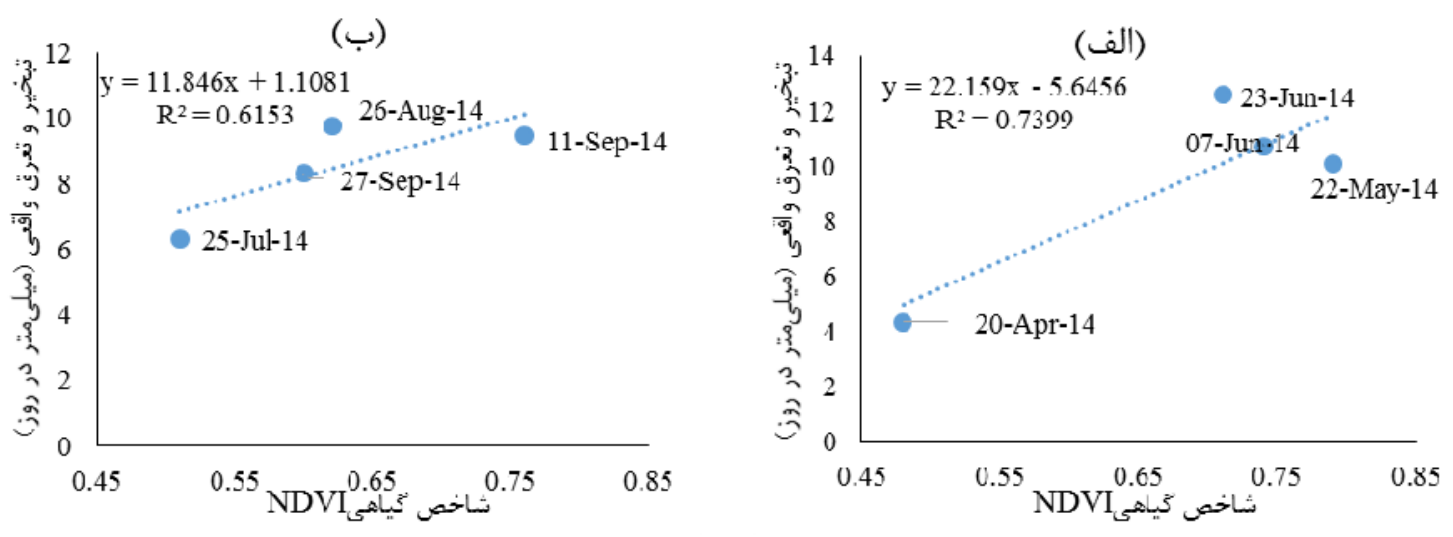

شكل VIV ارتباط مقادير NDVI-ETC در زمين شماره ينج در سال ساهץ: الف) كشت اول و ب) كشت دوم
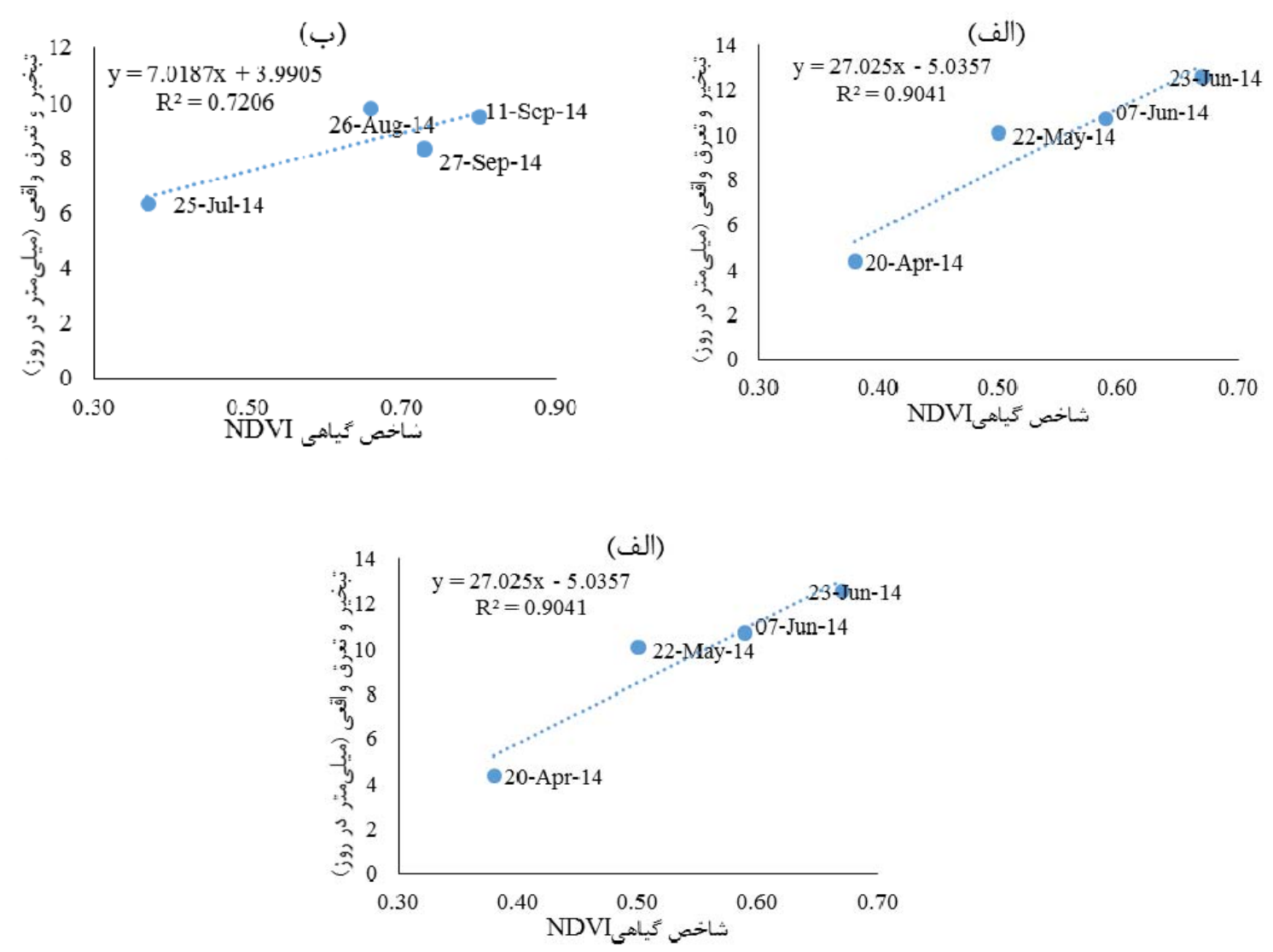

شكل \1. ارتباط مقادير NDVI-ETC در زمين شماره شش در سال Y Y Y. الف) كشت اول و ب) كشت دوم

لازم به ذكر است كه با بررسى نتايج حاصل از شـاخص NDVI

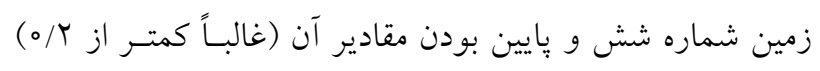
در هشت تصوير مورد مطالعه مربوط بـه مـاههـاى مختلـف دو

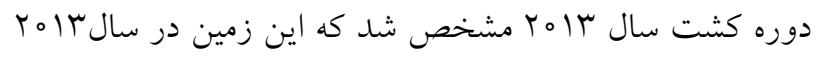
تحت كشت قرار نخرفته و فاقد بوشش بوده است. مقادير پيايين
كاهش ميزان شاخص NDVI در آخــرين تـاريخ تصـوير مـورد

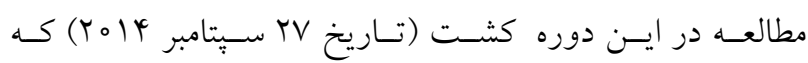
مصادف با انجام عمليات برداشـت محصـول در اوايـل مهرمـاه است، نشاندهنده كاهش تراكم بوشش زمين و درنتيجه كـاهش ضريب همبستخى است. 
مى توان اين مدل رياضى را در هر زمان بــا اسـتفاده از تصـاوير ماهو اره لندست بهروزرسانى كرد.

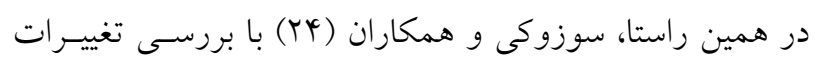

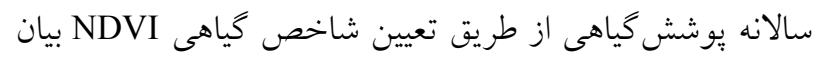

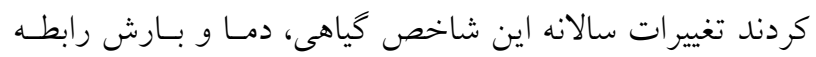
مستقيمى با تغييرات سالانه تبخير و تعرق داشته است.

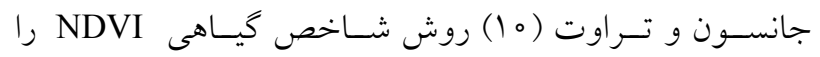
بهعنوان روشى دقيق و كمهزينه براى تعيين ميزان تبخير و تعرق

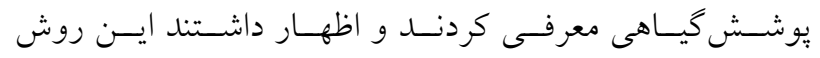

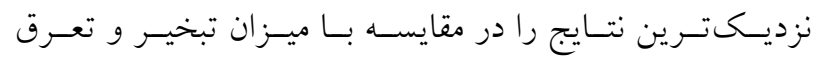

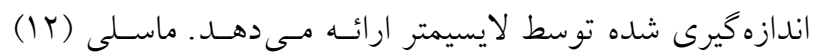

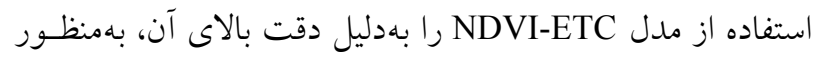
پايش و ارزيابى تبخير و تعرق در مقياس منطقهاى توصيه كرد.

\section{نتيجه گيرى}

هدف از يزوهش حاضر، ارزيابى كارايى شاخص گياهى NDVI

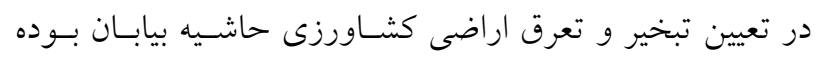

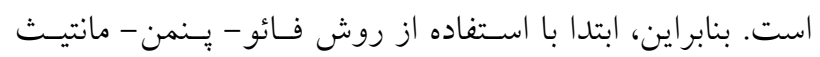

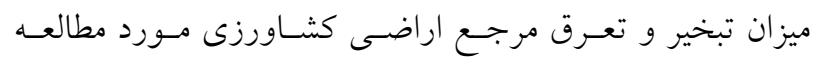

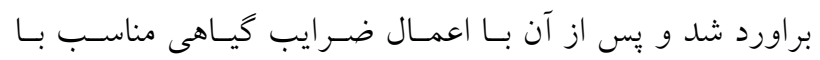

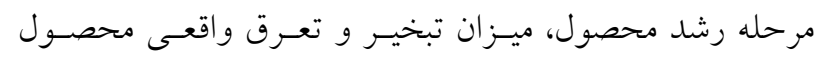

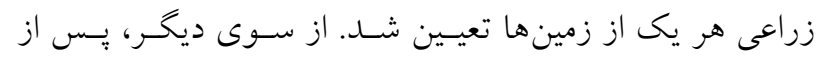

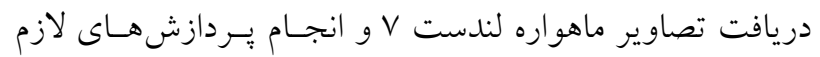
روى آنها، شاخص NDVI محاسـبه و درنهايست، ارتبـاط ميـان

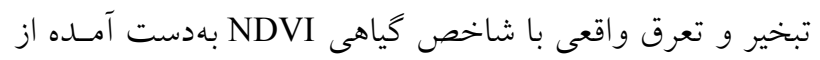
دادههاى ماهو ارهاى بررسى شد.

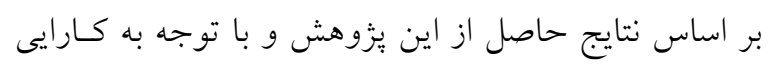

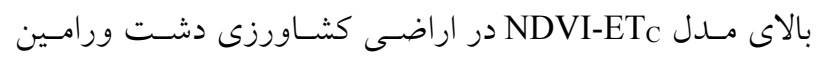

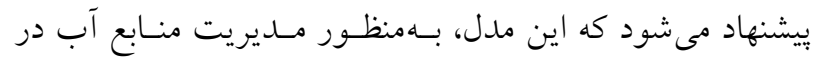

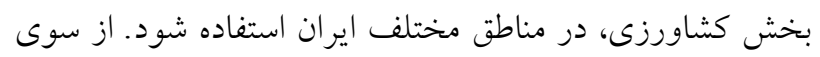

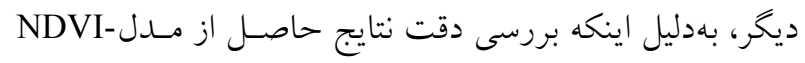
ETC
شاخص NDVI در اين ماهها نيز حاكى از اين است كـه ميـزان

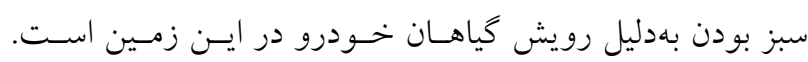

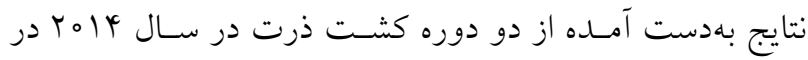

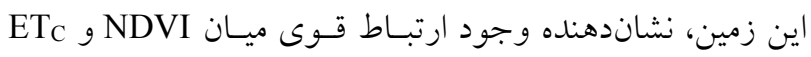
است (شكل 1) (1).

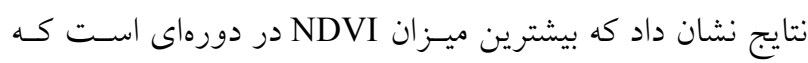

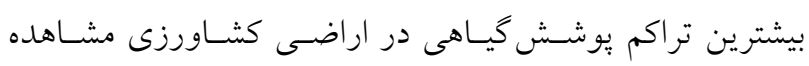

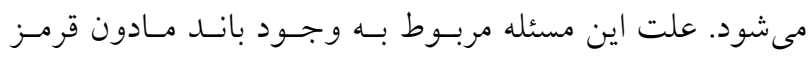

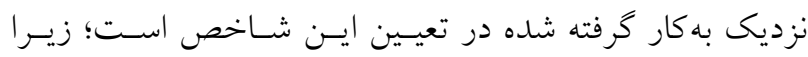

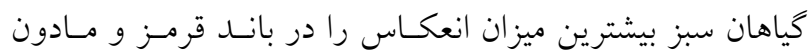

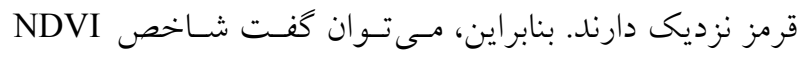
شاخصى مفيد براى بررسى و تعيين وضعيت يوشـش زمسين در اراضى كشاورزى است. همجينين، مى توان اظهار داشـت كـه بـا

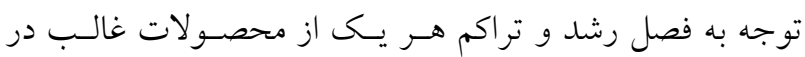

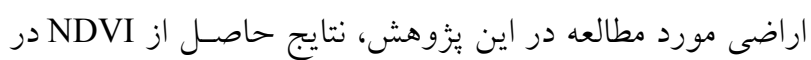
محدوده قابل قبولى قرار دارند.

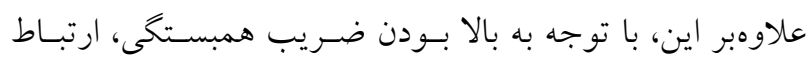

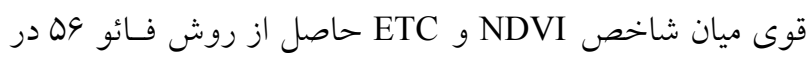

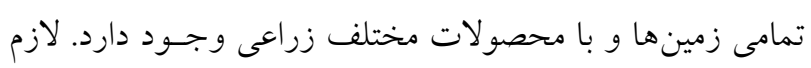

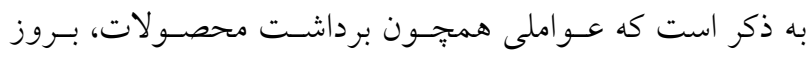

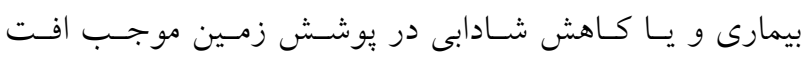

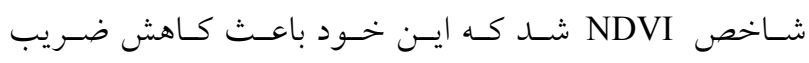

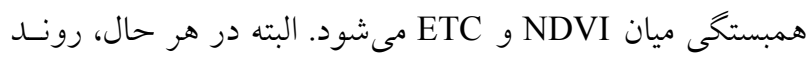
ثابت و مثبتى ميان تغييرات NDVI و ETC قابل مشاهده است.

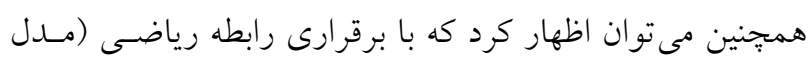

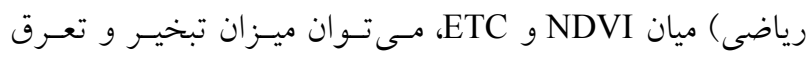

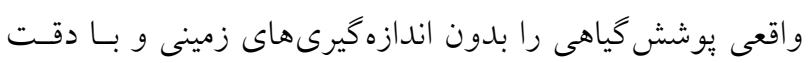

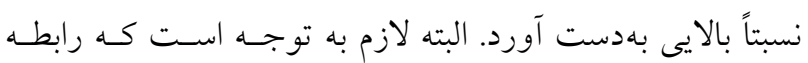

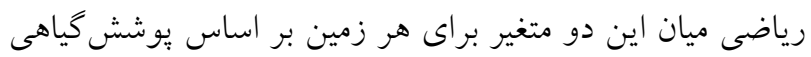
موجود در آن متفاوت خواهد بـود كـه طـى يـك بـار عمليـات

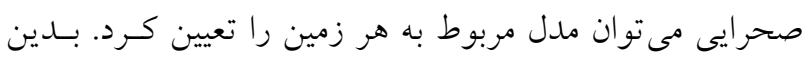

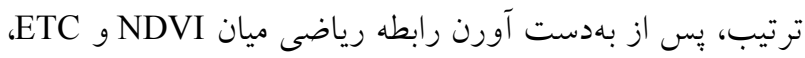




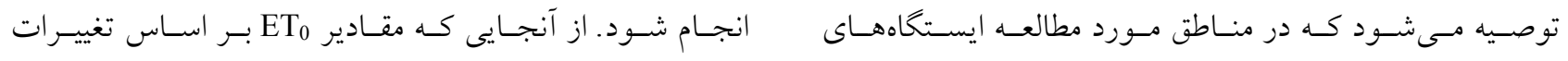

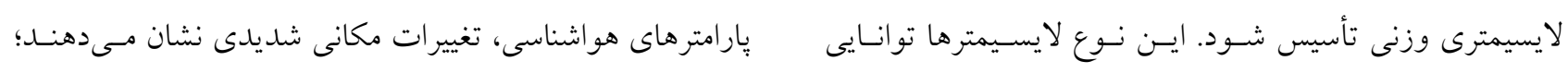

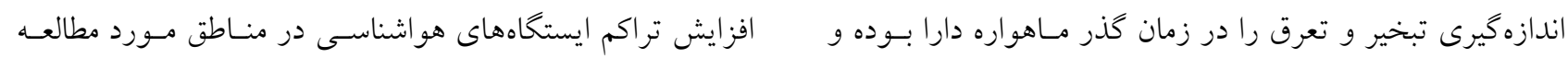

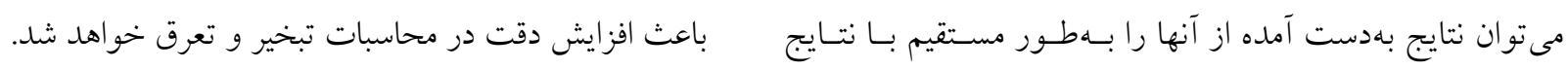

$$
\begin{aligned}
& \text { حاصل از دادههاى مـاهوارهاى مقايسـه كـرد و اصـلاحات لازم }
\end{aligned}
$$

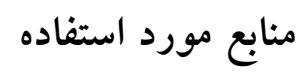

1. Alizadeh, H. A. 2014. Dynamic Modeling of Wastewater Utilization with Sustainable Agriculture Approach (Case Study: Varamin Plain). PhD Thesis, Department of Irrigation Engineering, Colleage of Agricultura and Natural Resources, University of Tehran.

2. Dodds, P. E., A. Barton and W. S. Meyer. 2005. Review of Methods to Estimate Irrigated Reference Crop Evapotranspiration Across Australia. CRC for Irrigation Futures Technical Report No 04/05, 48 pp.

3. Drerup, P., H. W. Brueck and H. Scherer. 2017. Evapotranspiration of winter wheat estimated with the FAO 56 approach and NDVI measurements in a temperate humid climate of NW Europe. Agricultural Water Management 192: $180-188$.

4. Farg, E., S. M. Arafat, M. A. El-Wahed and A. M. EL-Gindy. 2012. Estimation of Evapotranspiration ETc and Crop Coefficient Kc of Wheat, in south Nile Delta of Egypt Using integrated FAO-56 approach and remote sensing data. The Egyptian Journal of Remote Sensing and Space Science 15(1):83-9.

5. Farshi, A. A. 1998. An estimate of water requirement of main field crops and orchards in Iran. Iranian Water and Soil Research Institute, pp. 900.

6. Glenn, E. P., P. L. Nagler and A. R. Huete. 2010. Vegetation index methods for estimating evapotranspiration by remote sensing. Surveys in Geophysics 31(6): 531-55.

7. Hekmaat Pour., L., S. Faiznia, H. Ahmadi and A. Khalil Pour. 2007, Zoning suitable areas for artificial nutrition in Varamin plain using GIS and decision support system. Environmental Studies 33(42): 1-8.

8. Holm, A. M., D. G. Burnside and A. A. Mitchell. 1987. The development of a system for monitoring trend in range condition in the arid shrublands of Western Australia. The Rangeland Journal 9(1): 14-20.

9. Iran Water Resources Management Company. 2010, Studies of updating the water resources balance in the salt lake study period, Water and Sustainable Development Consulting Engineers.

10. Johnson, L. F. and T. J. Trout. 2012. Satellite NDVI assisted monitoring of vegetable crop evapotranspiration in California's San Joaquin valley. Remote Sensing 4(2): 439-455.

11. Johnson, T. D. and K. Belitz. 2012. A remote sensing approach for estimating the location and rate of urban irrigation in semi-arid climates. Journal of Hydrology 414: 86-98.

12. Maselli, F., D. Papale, M. Chiesi, G. Matteucci, L. Angeli, A. Raschi and G. Seufert. 2014. Operational monitoring of daily evapotranspiration by the combination of MODIS NDVI and ground meteorological data: Application and evaluation in Central Italy. Remote Sensing of Environment 152: 279-290.

13. Mobasheri, M. R and H. F. Khavarian. 2014. Analysis of Satellite Usage Methods for Evaluation of Evapotranspiration Rate. Scientific Journals Management System 3(4): 83-98.

14. Molden, D., T. Y. Oweis, S. Pasquale, J. W. Kijne, M. A. Hanjra, P. S. Bindraban, B. A. Bouman, S. Cook, O. Erenstein, H. Farahani and A. Hachum. 2007. Pathways for increasing agricultural water productivity. Water for food, water for life: a Comprehensive Assessment of Water Management in Agriculture. ondon, UK: Earthscan; Colombo, Sri Lanka. International Water Management Institute (IWMI) 279-310.

15. Nagler, P. L., E. P. Glenn, T. L. Thompson and A. Huete. 2004. Leaf area index and normalized difference vegetation index as predictors of canopy characteristics and light interception by riparian species on the Lower Colorado River. Agricultural and Forest Meteorology 125(1): 1-17.

16. Nouri, H., S. Anderson, S. Beecham and D. Bruce. 2013. Estimation of Urban Evapotranspiration through Vegetation Indices Using worldview2 Satellite Remote Sensing Images (Doctoral dissertation, Commission Internationale du Genie Rural).

17. Nouri, H., S. Beecham, F. Kazemi and A. M. Hassanli. 2013. A review of ET measurement techniques for estimating the water requirements of urban landscape vegetation. Urban Water Journal 10(4): 247-259.

18. Nouri, H., S. Beecham, F. Kazemi, A. M. Hassanli and S. Anderson. 2013. Remote sensing techniques for predicting evapotranspiration from mixed vegetated surfaces. Hydrology and Earth System Sciences Discussions 10(3): 3897-3925. 
19. Nouri, H., S. Beecham, S. Anderson and P. L. Nagler. 2014. High spatial resolution WorldView-2 imagery for mapping NDVI and its relationship to temporal urban landscape evapotranspiration factors. Remote Sensing 6(1): 580-602.

20. Nouri, H., S. Beecham, S. Anderson, A. M. Hassanli and F. Kazemi. 2015. Remote sensing techniques for predicting evapotranspiration from mixed vegetated surfaces. Urban Water Journal 12(5): 380-393.

21. Organization Agriculture-Jihad Tehran, 2012, http://tehran.agri-jahad.ir.

22. Rafiee Eman, A. and G. Zehtabian. Investigation of factors affecting land Degradation in Varamin Plain. 2006. Iranian Journal of Natural Resources 59(2): 289-298.

23. Reyes-González, A., J. Kjaersgaard, T. Trooien, C. Hay and L. Ahiablame. 2018. Estimation of Crop Evapotranspiration Using Satellite Remote Sensing-Based Vegetation Index. Advances in Meteorology 2018: 1-13.

24. Suzuki, R., K. Masuda and D. G. Dye. 2007. Interannual covariability between actual evapotranspiration and PAL and GIMMS NDVIs of northern Asia. Remote Sensing of Environment 106(3): 387-398.

25. Trout, T. J., L. F. Johnson and J. Gartung. 2008. Remote sensing of canopy cover in horticultural crops. HortScience 43(2): 333-337. 


\title{
Estimation of Virtual Water and Water Requirement of Desert Margin Vegetation Using Satellite Images (A Case Study: Varamin Plain)
}

\author{
B. Noori ${ }^{1}$, H. Nouri ${ }^{2}$, GH. Zehtabian ${ }^{1}$, A. H. Ehsani ${ }^{3}$, H. Khosravi ${ }^{1^{*}}$ \\ and $\mathrm{H}$. Azarnivand ${ }^{1}$
}

(Received: November 18-2018 ; Accepted: March 4-2019)

\begin{abstract}
Due to the impact of climate change on the plant water demand and the availability of water, especially in drylands, it is vital to estimate the evapotranspiration rates accurately. In this study, the vegetation status in the marginal desert areas of Varamin Plain was studied, and the actual evapotranspiration and water demand of intercropped farms were assessed. This study also evaluated the potential relationship between the evapotranspiration of different agricultural lands and their vegetation index using remote sensing techniques. A collection of satellite images from Landsat 7 in consecutive seasons was used to determine the greenness rate of marginal desert areas during 2013 and 2014. ENVI software was used for the image processing, which included geometric corrections and atmospheric corrections, to develop NDVI maps. Also, weather data and crop properties of Varamin Plain were collected, and the actual evapotranspiration rate of plant cover was estimated using CropWat. The correlation between NDVI extracted from satellite images and the evaluated evapotranspiration rate was assessed. The results showed a strong relationship between evapotranspiration of heterogeneous agricultural lands and NDVI. This confirmed that the NDVI derived by remote sensing approach could be a useful index to evaluate vegetation status and water demand of farmlands in the desert borders.
\end{abstract}

Keywords: Evapotranspiration, Remote sensing, NDVI, FAO- Penman- Monteith, Varamin plain

\footnotetext{
1. Department of Arid and Mountainous Regions Reclamation, Faculty of Natural Resources, University of Tehran, Tehran, Iran.

2. Water Engineering and Management, Division of Agronomy, University of Gottingen, Germany.

3. Environmental Design Engineering, Faculty of Environment, University of Tehran, Tehran, Iran.

*: Corresponding author: hakhosravi@ut.ac.ir
} 